\title{
INTEGRATED NUTRIENT MANAGEMENT IN POTATO WITH COMPOST MADE THROUGH DIFFERENT BIO-DEGRADATION PROCESSES
}

\author{
K Mukhopadhyay, SH Ansary, S Saha, M Debnath, MK Kundu, SJ Pramanick, SC Dhang, S Islam
}

Nadia Krishi Vigyan Kendra, Bidhan Chandra Krishi Viswavidyalaya, Indian Council of Agricultural Research, Gayeshpur, Nadia, West Bengal, Pin-741234, India

Received - April 29, 2021; Revision - July 07, 2021; Accepted - July 13, 2021

Available Online - October 20, 2021

DOI: http://dx.doi.org/10.18006/2021.9(Spl-3-NRMCSSA_2021).S306.S313

\section{KEYWORDS \\ Integrated nutrient management \\ Composting process \\ Potato \\ Yield}

Economics

\begin{abstract}
To achieve the goal of safe and sustainable food, the only realistic option now-a-days lies with the introduction of a low input farming system concept i.e. organic and integrated agriculture. Keeping in view the present scenario, a study was undertaken in Satyapole village, Haringhata block of Nadia district, West Bengal on integrated nutrient management in potatoes during rabi 2018 and 2019. The efficacy of different composts, in terms of their quality, easiness of preparation along with yield and economic attributes were accessed for the high nutrient loving crop, potato. The experiment was planned out in randomized block design (RBD) with 5 treatments and 4 replications. High yield with a marginal difference was found among all the treatments with integrated management. But, the treatment with $50 \%$ of recommended inorganic fertilizer dose (recommended dose N:P: K @ 200:150:150 kg/ha, 1/3 $\mathrm{N}$, full $\mathrm{P}$ and $1 / 3 \mathrm{~K}$ as basal; $1^{\text {st }}$ and $2^{\text {nd }}$ top dressing with $1 / 3 \mathrm{~N}$ and $1 / 3 \mathrm{~K}$ ) and vermicompost @ 5 ton/ha showed the best result. According to the B: C ratio composting with NOVCOM showed the best result whereas, in terms of the bio-degradation process with respect to its end-product quality, easiness of procedure, and cost, compost made through waste decomposer and NOVCOM has better results in comparison with vermicompost.
\end{abstract}

* Corresponding author

E-mail: kaushikmbrp@gmail.com, nadiakvk@gmail.com(K. Mukhopadhyay)

Peer review under responsibility of Journal of Experimental Biology and Agricultural Sciences.

Production and Hosting by Horizon Publisher India [HPI] (http://www.horizonpublisherindia.in/).

All rights reserved.
All the articles published by Journal of Experimental Biology and Agricultural Sciences are licensed under a Creative Commons Attribution-NonCommercial 4.0 International License Based on a work at www.jebas.org.

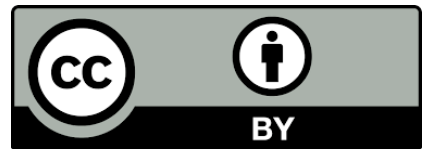




\section{Introduction}

Potato (Solanum tuberosum L.) is considered to be the $3^{\text {rd }}$ most important consumable crop worldwide just after rice and wheat (International Potato Center, 2013). India is the second largest producer of potatoes and shares $38 \%$ of the total world production along with China (PTI, 2020). Besides, potato is considered as the fourth most important food crop in India after rice, wheat, and maize (Ojha \& Saha, 2014); occupying 21.8 lakh ha area with a production of 52.5 MT currently (Ghosh, 2020). Among the Indian states, West Bengal is one of the major growers of potato sharing almost $24.92 \%$ of the country's production after Uttar Pradesh (30.33\%) (NHB, 2017-18).

As a consequence, only reliance on chemical fertilizers cannot ensure sustainable crop production along with changing climatic patterns and declining soil productivity indicators (Mollah et al., 2011). But, at the same time to mitigate these adverse effects, complete reliance on organic farming is a challenging task particularly for a highly nutrient-requiring crop like potato. Poneisio et al. (2015) has conducted a meta-analysis comparing the yield gap between organic practices and conventional ones. The investigation has shown a reduction in yield gap up to $4-9 \%$ in organic practices under diversification of crops, multi-cropping system, and crop rotation phenomenon as compared with conventional practices. These suggested agroecological approaches may be the key. It is considered that the production of a sufficient quantity of good quality organic manure to support proper nutrition isn't practically viable for our small and marginal farmers. Another important hindrance is the unavailability of a quicker, easier, costeffective bio-degradation process which is the only way to ensure the recycling of on-farm waste into quality compost.

An integrated approach combining organic and inorganic sources of the nutrient is necessary towards achieving future agricultural goals as it not only sustains the production system but also helps in restoring soil health through maintaining soil fertility (Nambiar, 1998). Thus, keeping in view of this context, the present study was conducted with the objectives to access the potential of integrated nutrient management against a complete inorganic package of practice along with farmers' practice in terms of yield, economics, and soil quality and to evaluate three different composting processes viz. vermicomposting, composting with waste decomposer and Novcom composting method regarding their cost of production, quality of end product and process convenience.

\section{Materials and methods}

\subsection{Study area}

The present study was carried out during the rabi season of 2018 and 2019 at Satyapole village of Haringhata block, Nadia district, West Bengal, India. The area is located between $22.92^{\circ} \mathrm{N}$ latitude to $88.58^{\circ} \mathrm{E}$ longitudes. The soils of the area are neutral to slightly acidic, loam to sandy loam texture having good drainage facility and have moderate to high nutrient content.

\subsection{Cultivation details}

The potato variety selected for the present study was Super-6. The investigation was carried out in randomized block design (RBD) with 5 treatments and 4 replications. Tubers were planted from $14^{\text {th }}$ to $21^{\text {st }}$ November and harvested from $28^{\text {th }}$ February to $8^{\text {th }}$ March (both years). Planting was done with $750 \mathrm{~kg}$ of tuber per ha following a distance of $60 \mathrm{~cm}$ row to row and $25 \mathrm{~cm}$ plant to plant. In each hill, one seedling was planted. The details of technologies selected for the study are shown in Table 1.

All the recommended practices were implemented at the time of experiment set up. After 100 days of planting the crop, the haulm was cut accordingly. To allow tuber curing in the field crops were harvested after ten days of haulm cutting.

Agronomic parameters and yield attributes were recorded properly. Agronomic parameters were measured after the selection of ten plants from each plot randomly. Plant height was recorded after 30 days after planting (DAP). Other parameters i.e., plant height, number of leaves per plant, and number of the shoot were recorded at $60 \mathrm{DAP}$. The height of the tallest shoot was measured from the soil surface to the last leaf unfolded at 60 DAP. The total count and weight mass of tubers were also recorded at harvest.

Table1 Treatment schedule

Treatment No.

$\mathrm{T}_{1}$

$\mathrm{T}_{2}$

$\mathrm{T}_{4}$

$\mathrm{T}_{5}$
Treatment details

Farmers' practice (Imbalanced fertilization without adding any organic input)

Recommended inorganic practices i.e. $\mathrm{N}: \mathrm{P}: \mathrm{K}=100: 150: 150 \mathrm{~kg} / \mathrm{ha}$

Basal dose: $1 / 3^{\text {rd }} \mathrm{N}+$ Full $\mathrm{P}+1 / 3^{\text {rd }} \mathrm{K}$

$1^{\text {st }}$ Top dressing (during $1^{\text {st }}$ earthing up): $1 / 3^{\text {rd }} \mathrm{N}+1 / 3^{\text {rd }} \mathrm{K}$

$2^{\text {nd }}$ Top dressing (during $2^{\text {nd }}$ earthing uo): $1 / 3^{\text {rd }} \mathrm{N}+1 / 3^{\text {rd }} \mathrm{K}$

$50 \%$ of $\mathrm{T}_{2}+$ Vermicompost (@ 5ton/ha)

$50 \%$ of $\mathrm{T}_{2}+$ Compost from Waste Decomposer (@ 5ton/ha)

$50 \%$ of $\mathrm{T}_{2}+$ Novcom Compost (@ 5ton/ha)

Journal of Experimental Biology and Agricultural Sciences

http://www.jebas.org 


\subsection{Composting methodologies}

\subsubsection{Vermi composting}

Vermicompost was prepared following standard methodology in a low-cost Vermi shed. Compost was made in the pit after green raw materials of agricultural fields were semi decomposed followed by the addition of earth warm species Esenia foetida@10-12 in number for per $\mathrm{kg}$. of semi decomposed organic waste. Thus, matured vermicompost was ready for application within 50-60 days.

\subsubsection{Compost using waste decomposer solution}

A waste decomposer is a microbial consortium produced by the National Centre of Organic Farming (NCOF), Gaziabad, U.P. Mass multiplication solution of waste decomposer was done by following the standard procedure as laid down in the manual of NCOF. The solution thus made from one bottle of waste decomposer has multiple uses including preparation of compost in a faster manner. The details of the composting method using waste decomposer stock solution also followed the NCOF manual. It is an easy process by which good quality matured compost could be obtained within 35-40 days.

\subsubsection{Novcom Compost}

Novcom composting is already a well recognized scientific method of compost preparation through the use of Novcom solution, a biologically activated and potentized extract of doob grass
(Cynodon dactylon), Bel (Sida cordiflolia L.), and common basil (Ocimum basellicium). In this method, good quality matured compost was produced on the farm within 21-25 days as per the procedure documented by Bera et al. (2013).

\subsection{Analytical methods}

Mature compost samples from each type were drawn and were analyzed for different physicochemical properties, nutrient content, and microbial status. Total N, P, K content in compost was determined by the acid digestion method (Jackson, 1973) and organic carbon content was done by the procedure outlined by Allison (1965). Compost stability test (viz. $\mathrm{CO}_{2}$ evolution rate) and phytotoxicity bio-assay test of compost were performed according to the procedure suggested by Trautmann \& Kransy (1997). Surface soil samples $(0-25 \mathrm{~cm})$ from pre and post-experiment plots were collected and analysis was done for soil physicochemical and nutrient properties observing standard methodologies (Allison, 1965; Jackson, 1973).

\section{Results and discussion:}

\subsection{Quality parameters of different compost:}

Quality parameters of different types of compost according to their physicochemical, nutrient, and biological properties are presented in Table 2. The characteristics of mature compost are necessary to have appeared in dark brown color with an earthy smell (Epstein, 1997). The average moisture content of the compost samples ranged from 52.44 to 56.26 percent, which

Table 2 Quality parameters of different compost produced at Nadia KVK

\begin{tabular}{|c|c|c|c|}
\hline \multirow{2}{*}{ Parameter } & \multicolumn{3}{|c|}{ Analytical Value } \\
\hline & Vermi compost & Waste Decomposer compost & Novcom compost \\
\hline Moisture percent $(\%)$ & 52.44 & 54.09 & 56.26 \\
\hline $\mathrm{pH}_{\text {water }}(1: 5)$ & 6.79 & 7.43 & 7.78 \\
\hline EC $(1: 5) \mathrm{dS} / \mathrm{m}$ & 1.53 & 1.61 & 2.09 \\
\hline Organic carbon $(\%)$ & 23.08 & 23.78 & 25.31 \\
\hline $\mathrm{CMI}^{1}$ & 2.11 & 2.12 & 2.07 \\
\hline Total nitrogen $(\%)$ & 1.58 & 1.78 & 1.89 \\
\hline Total phosphorus (\%) & 0.64 & 0.79 & 0.74 \\
\hline Total potassium $(\%)$ & 0.62 & 0.89 & 1.09 \\
\hline $\mathrm{C} / \mathrm{N}$ ratio & $14.61: 1$ & $13.36: 1$ & $13.39: 1$ \\
\hline Total bacterial count ${ }^{2}$ ( $\log _{10}$ value $)$ & 11.21 & 13.19 & 15.20 \\
\hline Total fungal count ${ }^{2}\left(\log _{10}\right.$ value $)$ & 10.54 & 11.43 & 15.04 \\
\hline Total actinomycetes count ${ }^{2}\left(\log _{10}\right.$ value $)$ & 10.07 & 11.07 & 14.76 \\
\hline $\mathrm{CO}_{2}$ evolution rate $\left(\mathrm{mgCO}_{2}-\mathrm{C} / \mathrm{g} \mathrm{OM} /\right.$ day $)$ & 1.81 & 2.51 & 2.71 \\
\hline Germination index (phyto toxicity bioassay) & 0.87 & 0.83 & 0.95 \\
\hline
\end{tabular}

${ }^{1}$ CMI: Compost mineralization index; ${ }^{2}$ Colony forming unit c.f.u. per g moist compost expressed as $\log _{10}$ value

Journal of Experimental Biology and Agricultural Sciences

http://www.jebas.org 
showed the high-value range (40-50\%) according to Evanylo (2006). $\mathrm{pH}$ values ranged from 7.2 to 8.5 for waste decomposer compost and Novcom compost samples which lied within the specified range as suggested for good quality compost (Jime`nez \& Garcia, 1989). As suggested by USCC (2002), the organic carbon content in compost must be within the range of 16-38 percent for application in crop fields. The samples thus prepared for application had organic carbon content in between 23.08 and 25.31 percent. Compost mineralization index (CMI) is described as the ash content divided by oxidizable carbon which varied from 2.07 to 2.11. All samples are within the stipulated range ( 0.79 to 4.38$)$ as suggested by Rekha et al. (2005).

Alexander (1994) suggested that the total nitrogen content range in good quality compost is ranged from 1 to 2 percent. The total nitrogen content for the compost samples under study was varied between 1.58 and 1.89 percent which falls under the standard reference range.

The highest nitrogen content (1.89 percent) was found in Novcom compost preferably due to the highest fixation of atmospheric nitrogen under the Novcom composting method as suggested by Seal et al. (2012). The total phosphate and total potash content were 0.64 to 0.76 percent and 0.62 to 1.09 percent respectively which were higher than the minimum suggested standard range (phosphate 0.6 to 0.9 percent and potash 0.2 to 0.5 percent) (Alexander, 1994). C/N ratio varied from 13.36:1 to $14.61: 1$ indicating that all the compost samples could be readily applicable in soil.

Microbial status is considered to be the key factor for good quality compost production and side by side plays a pivotal role in maintaining soil nutrient dynamics through sustaining soil health. Total bacteria, total fungi, and total actinomycetes count in Novcom compost was significantly higher than the other compost samples which fall in the order of $10^{16-}$ c.f.u to $10^{14-}$ c.f.u. Microbial respiration formed an important parameter for the determination of compost stability (Gómez et al., 2006).
The stipulated range of mean respiration or $\mathrm{CO}_{2}$ evolution rate is 2 to $5 \mathrm{mg}$ /day for quality stable compost as suggested by Trautmann \& Kransy (1997). The mean respiration rate for the compost samples under study was found within the standard range of 1.81 to $2.71 \mathrm{mg} / \mathrm{day}$. The phytotoxicity bioassay test mainly represents the combined toxicity of contaminants present within the measuring limit of the germination index (Zucconi et al., 1985). It is portrayed through the investigation that the compost samples were free from any phytotoxic effect beneath the reference value of 0.8 to 1.0 (Trautmann \& Krasny, 1997).

\subsection{Growth and yield attributes}

Emergence percentage varied between as low as $92.3 \%$ for farmers' practice to as high as $99.7 \%$ for the INM treatment with vermicompost $\left(\mathrm{T}_{3}\right)$ (Table 3). The mean value for emergence was highest $(98.5 \%)$ for the same also followed by INM with Novcom compost (97.7\%). At 60 days crop growth stage, the height of the plant and compound leaves per plant varied significantly under different farming conditions. INM treatment with Novcom compost $\left(\mathrm{T}_{5}\right)$ showed a mean maximum plant height of $32.6 \mathrm{~cm}$ and the mean value of the number of compound leaves per plant was found highest for the INM treatment combining with waste decomposer compost.

The results followed the identical pattern for the total number of tuber and tubers above processing grade of $>45 \mathrm{~mm}$. A marked difference was observed among INM plots in comparison to the farmers' practice and chemically fertilized plots. Incorporation of organic manure highly influences the beneficial microorganisms to colonize in the rhizosphere and accelerate plant growth through essential nutrients and also help to synthesize some plant hormones and as a result of which profound increase is observed in plant height, leave number and weight of tuber whatever may be the potato variety (Venkatasalam et al., 2012). Shubha et al. (2018) also observed better growth and yield attributes for potato under integrated nutrient management.

Table 3 Growth Attributes of Potato under different treatments

\begin{tabular}{|cccccc|} 
Treatments & Emergence (\%) & Plant height $(\mathrm{cm})$ & No. of compound leaves /plant & \multicolumn{2}{c|}{ No. of tuber (thousand/ha) } \\
& & & $44.2-46.8(44.6)$ & 178.43 & 266.25 \\
\hline $\mathrm{T}_{1}$ & $92.3-95.8(94.1)$ & $24.1-27.3(25.2)$ & $46.6-53.8(48.6)$ & 190.51 & 269.83 \\
\hline $\mathrm{T}_{2}$ & $93.7-96.1(94.6)$ & $27.1-29.3(28.6)$ & $45.6-53.8(49.8)$ & 192.56 & 305.61 \\
\hline $\mathrm{T}_{3}$ & $97.4-99.7(98.5)$ & $27.7-30.8(29.1)$ & $44.8-53.7(50.3)$ & 193.14 & 279.39 \\
\hline $\mathrm{T}_{4}$ & $93.1-96.4(94.7)$ & $27.3-31.8(29.5)$ & $48.3-54.4(50.2)$ & 196.68 & 300.70 \\
\hline $\mathrm{T}_{5}$ & $97.1-99.6(97.7)$ & $29.4-34.1(32.6)$ & 2.76 & 3.27 & 3.90 \\
\hline $\mathrm{P}=0.05$ & 2.15 & 1.87 & & & Total \\
\hline
\end{tabular}

Figure in parenthesis represented mean value

Journal of Experimental Biology and Agricultural Sciences http://www.jebas.org 
Table 4 Nutrient use efficiency (NUE) and yield

\begin{tabular}{|ccc|}
\hline Treatments & Tuber Yield (ton/ha) & NUE* $(\mathrm{kg} / \mathrm{kg}$ NPK) \\
\hline $\mathrm{T}_{1}$ & 29.05 & 22.42 \\
\hline $\mathrm{T}_{2}$ & 30.68 & 21.21 \\
\hline $\mathrm{T}_{3}$ & 33.32 & 68.12 \\
\hline $\mathrm{T}_{4}$ & 32.68 & 63.01 \\
\hline $\mathrm{T}_{5}$ & 32.94 & 69.01 \\
\hline $\mathrm{P}=0.05$ & 1.17 & 2.20 \\
\hline
\end{tabular}

*NUE was evaluated in terms of 'Partial Factor Productivity' of applied nutrients $\left(\mathrm{PFP}_{\mathrm{NPK}}\right)$

Table 5 Soil Physico-chemical properties under different treatments

\begin{tabular}{|c|c|c|c|c|c|c|c|}
\hline Treatments & $\mathrm{pH}(1: 2.5)$ & $\mathrm{EC}\left(\mathrm{dSm}^{-1}\right)$ & Org.- C (\%) & Av.- N & Av.- $\mathrm{P}_{2} \mathrm{O}_{5}$ & Av.- $\mathrm{K}_{2} \mathrm{O}$ & Av.- $\mathrm{SO}_{4}$ \\
\hline $\mathrm{T}_{1}$ & 6.56 & 0.031 & 0.65 & 322.20 & 55.41 & 223.36 & 25.53 \\
\hline $\mathrm{T}_{2}$ & 6.48 & 0.033 & 0.68 & 327.18 & 60.35 & 198.30 & 27.89 \\
\hline $\mathrm{T}_{3}$ & 6.61 & 0.030 & 0.61 & 312.11 & 59.11 & 235.51 & 32.11 \\
\hline $\mathrm{T}_{4}$ & 6.51 & 0.029 & 0.70 & 351.3 & 63.83 & 230.12 & 23.75 \\
\hline $\mathrm{T}_{5}$ & 6.49 & 0.037 & 0.62 & 333.63 & 60.16 & 208.48 & 24.37 \\
\hline $\mathrm{P}=0.05$ & 0.28 & 0.004 & 0.04 & 4.99 & 3.15 & 4.96 & 2.11 \\
\hline
\end{tabular}

\subsection{Nutrient use efficiency (NUE) and yield}

Evaluation of nutrient use efficiency (NUE) in terms of partial factor productivity of applied nutrients $\left(\mathrm{PFP}_{\mathrm{NPK}}\right)$ were done for all the treatment plots and presented in Table 4. The value of NUE was much higher for the treatments of INM than farmers' practice and chemically managed plots. It was found highest for $\mathrm{T}_{5}$ (INM with Novcom compost) followed by $\mathrm{T}_{3}$ (INM with vermicompost) and $\mathrm{T}_{4}$ (INM with Waste decomposer compost). Karim \& Ramasamy (2000) suggested that the decline in $\mathrm{PFP}_{\mathrm{NPK}}$ may be due to the combined effect of imbalanced nutrition, a declining supply of indigenous soil-NPK and subsoil compaction, reduction in root volume along with escalation in the pest-disease attack. It is suggested that higher partial factor productivity particularly depends on the adoption of efficient nutrient management practices (Yadav, 2003).

The good yield was obtained from all the treatment plants though maximum tuber yield was found in $\mathrm{T}_{3}$ (INM with vermicompost) followed by $\mathrm{T}_{5}$ (INM with Novcom compost), $\mathrm{T}_{4}$ (INM with Waste decomposer compost), $\mathrm{T}_{2}$ (Recommended fertilizer dose), and $\mathrm{T}_{1}$ (Farmers' practice, without addition of any organic matter and imbalanced fertilization @240-250 kg of N/ha, 180-200 kg $\mathrm{P}_{2} \mathrm{O}_{5}$ and $\mathrm{K}_{2} \mathrm{O} / \mathrm{ha}$ ). According to Mohapatra et al. (2008) and Kumar et al. (2011), a significant influence on the application of organic manure in tuber yield of potato was also observed.

\subsection{Soil quality}

Soil physicochemical properties were observed before starting the experiment and also after harvesting the crop (Table 5). The soils under study have a slightly acidic to neutral soil reaction with $\mathrm{pH}$ varying from 6.48 to 6.61 . Electrical conductivity (EC) was increased in the soils having treatment of INM reflecting steady nutrient mineralization. Similar increasing trend was also noticed for organic carbon content where composts were used. Soil food web structure and soil health could be improved with proper organic management practices with the increasing population of soil fungi, amoebae, and ciliate biomass, microbial activity with carbon and nitrogen concentrations (Kammlade, 2015). Among the treatments highest increase (12.9\%) for organic carbon over initial was found in $\mathrm{T}_{5}$ (INM with Novcom compost). Kushwah \& Singh (2011) referred that potato requires a higher amount of nutrients as it synthesizes more amount of dry matter than other food crops. The sustainability of any cropping system may be under serious threat if imbalanced and indiscriminate use of synthetic fertilizer is used without following any soil management practices (Jatav et al., 2013). Available nitrogen, phosphorus, potassium, and sulphate status increased under all the treatments. But, the rate of increase over the initial was found much higher among the treatments with INM except for available $\mathrm{K}_{2} \mathrm{O}$. And among the three treatments with different types of compost, the increasing trend was best where Novcom compost was used in integrated manure. 
Table 6 Economic under different treatments

\begin{tabular}{|cccccc|}
\hline Treatments & Gross cost/ha & Gross return/ha & B:C & Net income/ha & Returns per rupees invested \\
\hline $\mathrm{T}_{1}$ & 209282 & 268887 & 1.28 & 59605 & 0.28 \\
\hline $\mathrm{T}_{2}$ & 197536 & 283974 & 1.44 & 86438 & 0.44 \\
\hline $\mathrm{T}_{3}$ & 211791 & 308410 & 1.46 & 96619 & 0.46 \\
\hline $\mathrm{T}_{4}$ & 201481 & 302486 & 1.50 & 101005 & 0.50 \\
\hline $\mathrm{T}_{5}$ & 202111 & 304893 & 1.51 & 102782 & 0.51 \\
\hline
\end{tabular}

Table 7 Assessment of different bio-degradation processes according to process convenience \& cost

\begin{tabular}{|c|c|c|c|c|}
\hline Bio-degradation process & $\begin{array}{l}\text { Days needed to } \\
\text { prepare compost }\end{array}$ & Structural requirement & $\begin{array}{c}\text { Recovery efficiency } \\
(\%)\end{array}$ & $\begin{array}{c}\text { Cost of production per kg } \\
\text { (Rs.) }\end{array}$ \\
\hline Vermi-composting & $55-60$ & $\begin{array}{c}\text { Permanent or } \\
\text { Temporary }\end{array}$ & $38-45$ & 3.40 \\
\hline $\begin{array}{l}\text { Waste decomposer } \\
\text { compost }\end{array}$ & $35-40$ & No need & $50-58$ & 2.45 \\
\hline NOVCOM compost & $21-25$ & No need & $52-60$ & 2.25 \\
\hline
\end{tabular}

\subsection{Economics}

The gross cost of potato cultivation per hectare (Table 6) was highest in the treatment with vermicompost as it involves much higher labor. But, in terms of gross return highest return was also obtained from the treatment with vermicompost, whereas B:C ratio was highest for $\mathrm{T}_{5}$ (INM with Novcom compost) as it involves the lesser cost of production among three different composting processes. Net return per ha and return per rupees invested were also highest with the treatment with Novcom compost followed by treatment with compost made through waste decomposer. Thus, the results showed the possibility of developing an integrated nutrient management option in terms of financial security also. Similar trend under potato cultivation with green farming was observed by Seal et al. (2017) with higher net income due to quality tuber yield.

\subsection{Process convenience and cost}

The detail of process convenience and cost involvement is shown in Table 7. In the vermicomposting method, about 55-60 days were needed to get mature compost. However, the challenging task was to keep the moisture within the reference range and protect the earthworms. The cost of vermicompost (Rs. 3.40/kg compost approx.) was also found to be the highest among the three studied processes. For compost production using the waste decomposer solution, no infrastructure was needed, but at least 5 turnings were required for getting mature compost within 35-40 days with green material and cow dung as raw inputs. Its cost was Rs. 2.45 (approx.) per kg compost. Novcom composting method also did not require any infrastructure and two turnings were sufficient for getting mature compost within 21-25 days. The cost was also the lowest (Rs. 2.25/kg mature compost) among the different studied composting methods. Except in the case of vermicompost, investment of family labor could bring down the cost below Rs. $1.30 / \mathrm{kg}$ for the other two composting methods. In terms of recovery efficiency also vermicompost has the lowest (38-45\%) than the other two composts (50-60\%).

\section{Conclusion}

The treatments with integrated management have a better result in terms of different growth attributes, yield, nutrient use efficiency, and soil health. Higher tuber yield, total tuber numbers, and tubers above processing grade under INM treatments indicated the positive influence of using good quality compost. Among the INM treatments, all three have comparable results in terms of tuber yield but, a marginally higher yield was found from the plots with vermicompost. In terms of economic sustenance higher B:C was found for the treatment with integrated nutrient management confirming the financial security under the system. According to different bio-degradation processes to its end-product quality, easiness of procedure, and cost, Novcom composting is found to be the best process.

\section{Conflict of Interest: Nil}

\section{References}

Alexander RA (1994) Standards and guidelines for compost use. Biocycle 35(12): 37-41.

Allison LE (1965) Organic carbon. In: Black CA (Ed.) Methods of soil analysis. Agronomy 9:1367-1389.

Bera R, Datta A, Bose S, Dolui AK, Chatterjee AK, Dey GC, Barik AK, Seal A (2013) Comparative evaluation of compost 
quality, process convenience and cost under different composting method to assess their large scale adoptability potential as also complemented by Compost Quality Index. International Journal of Scientific and Research Publication 3(6): 406-417.

Epstein E (1997) The science of composting. Technomic Publishing Company, USA Pp.383 - 415.

Evanylo G (2006) Compost maturity and indicators of quality: laboratory analyses and on-farm tests. Available at http://www.mawaterquality.org/industry_change/compost_school/ Compost\%20quality_Evanylo.pdf access on $29^{\text {th }}$ April 2021.

Gómez RB, Lima FV, Ferrer AS (2006) The use of respiration indices in the composting process: a review. Waste Managemen Research 24: 37-47.

Ghosh S (2020) Potato production rises 51\% to 52.5 million tonnes in over a decade: Agriculture minister Tomar. Available at https://www.indoasiancommodities.com access on $30^{\text {th }}$ January 2020.

International Potato Center (2013) CIP Annual Report 2013 Available at https://cgspace.cgiar.org access on $25^{\text {th }}$ January 2021.

Jackson ML (1973) Soil chemical Analysis. Prentice Hall of India Pvt. Ltd., New Delhi.

Jatav MK, Dua VK, Kumar M, Trehan SP, Kumar S (2013) Spatial distribution of soil available nutrients in the potato growing pockets of Hoshiarpur district of Punjab. Potato Journal 40 (2): 12-134.

Jime`nez IE, Garcia PV (1989) Evaluation of city refuse compost maturity: A Review. Biological Wastes 27: 115-42.

Kammalade SM (2015) Pototo tuber yield, quality, mineral nutrient concentration, soil health and soil food web in conventional and organic potato systems. M.Sc. Thesis submitted to Colorado State University, Fort Collins, Colorado.

Karim AA, Ramasamy C (2000) Expanding Frontiers of Agriculture: contemporary issues. Ludhiana, India: Kalyani Publishers.

Kumar M, Baishya LK, Ghosh DC, Gupta VK (2011) Yield and quality of potato (Solanum tuberosum) tubers as influenced by nutrient sources under rainfed conditions of Meghalaya. Indian Journal of Agronomy 56 (3): 260-266.
Kushwah VS, Singh SP (2011) Relative performance of low input and high input technology for potato production in India. Potato Journal 38 (1): 56-60.

Mohapatra BK, Maiti S, Satpathy MR (2008) Integrated nutrient management in potato (Solanum tuberosum) - Jute (Chorchorus olitorius) sequence. Indian Journal of Agronomy 53 (3): 205-209.

Mollah MRA, Islam N, Sarkar MAR (2011) Integrated nutrient management for potato-mung bean - T. aman rice cropping pattern under level Barind agroecological zone. Bangladesh Journal of Scientific and Industrial Research 36 (4): 711-722.

Nambiar KKM (1998) Integrated use of organic manures and chemical fertilizers in red soils for sustainable agriculture. In: Sehgal J, Blum WE, Gajbhiye KS (Eds.) Red and Lateritic soils; Vol-I, Managing red and lateritic soils for sustainable agriculture, Netherlands: Balkema Publishers, 367-376.

NHB (2017-18) Annual report of National Horticultural Board. Available at http://nhb.gov.in access on 25th January 2021.

Ojha MD, Saha B (2014) Organic potato in Nalanda (Bihar): Using eco-friendly Agril. Bios Inputs. Indian Research Journal of Extension Education 14 (3): 119-121.

Ponisio LC, M'Gonigle LK, Mace KC, Palomino J, Valpine P de, Kremen C (2015) Diversification practices reduce organic to conventional yield gap. Proceedings of the Royal Society B 282: 20141396.

Rekha P, Suman RDS, Aparna C, Hima BV, Anjaneyulu Y (2005) Bioremediation of contaminated lake sediments and evaluation of maturity indices as indicators of compost stability. International. Journal of Environmental Research on Public Health 2(2): 251-262.

PTI (2020) Available at https://www.ndtv.com access on 25th January 2021.

Seal A, Bera R, Chatterjee AK, Dolui AK (2012) Evaluation of a new composting method in terms of its biodegradation pathway and assessment of compost quality, maturity and stability. Archives of Agronomy and Soil Science 58 (9): 995-1012.

Seal A, Bera R, Datta A, Saha S, Roy Chowdhury R, Sengupta K, Barik AK, Chatterjee AK (2017) Evaluation of an organic package of practice towards integrated management of Solanum tuberosum and its comparison with conventional farming in terms of yield, quality, energy efficiency and economics. Acta Agriculturae Slovenica 109 (2): 363-382. 
Shubha AS, Srinivasa V, Shanwaz A, Anusha RB, Sharavathi MB (2018) Effect of Integrated Nutrient Management on Growth and Yield Attributes in Potato (Solanum tuberosum L.). International Journal of Current Microbiology and Applied Science 7(9): 830-836.

Trautmann NM, Krasny ME (1997) Composting in the classroom Available at http://www.cfe.cornell.edu/compost/schools.html access on 20th January, 2020.

U.S. Composting Council (2002) Available at http://www.compostingcouncil.org access on 25th January 2021.
Venkatasalam EP, Singh S, Sharma S (2012) Effect of organic manures on yield and yield attributing characters of potato. Potato Journal 39 (1): 84-87.

Yadav RL (2003) Assessing on-farm efficiency and economics of fertilizer N, P and $\mathrm{K}$ in rice wheat systems of India. Field Crops Research, 18: 39-51.

Zucconi F, Monaco A, Forte M (1985) Phytotoxins during the stabilization of organic matter. In: Gasser JKR (Ed.) Composting of agricultural and other wastes. Elsevier Applied Science Publication, New York, U.S.A, 73-86.

Journal of Experimental Biology and Agricultural Sciences http://www.jebas.org 